$10 / 2 / 21-80$

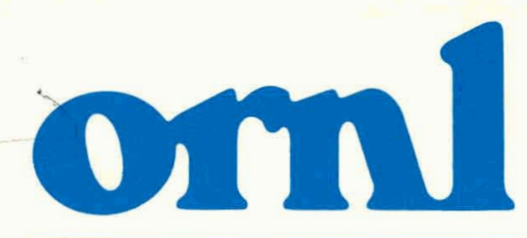

OAK

RIDGE

NATIONAL

LABORATORY

UNION

CARBIDE

\title{
MASTER
}

DR.754

ORNL/TM-7091

\section{Analysis of Fission-Product Effects in a Fast Mixed-Spectrum Reactor Concept}

\author{
J. R. White \\ T. J. Burns
}

OPERATED BY

UNION CARBIDE CORPORATION FOR THE UNITED STATES DEPARTMENT OF ENERGY 


\section{DISCLAIMER}

This report was prepared as an account of work sponsored by an agency of the United States Government. Neither the United States Government nor any agency Thereof, nor any of their employees, makes any warranty, express or implied, or assumes any legal liability or responsibility for the accuracy, completeness, or usefulness of any information, apparatus, product, or process disclosed, or represents that its use would not infringe privately owned rights. Reference herein to any specific commercial product, process, or service by trade name, trademark, manufacturer, or otherwise does not necessarily constitute or imply its endorsement, recommendation, or favoring by the United States Government or any agency thereof. The views and opinions of authors expressed herein do not necessarily state or reflect those of the United States Government or any agency thereof. 


\section{DISCLAIMER}

Portions of this document may be illegible in electronic image products. Images are produced from the best available original document. 
Printed in the United States of America. Available from National Technical Information Service

U.S. Department of Commerce

5285 Port Royal Road, Springfield, Virginia 22161

NTIS price codes-Printed Copy: A03; Microfiche A01

This report was prepared as an account of work sponsored by an agency of the United States Government. Neither the United States Government nor any agency thereof, nor any of their employees, makes any warranty, express or implied, or assumes any legal liability or responsibility for the accuracy, completeness, or usefulness of any information, apparatus, product, or process disclosed, or represents that its use would not infringe privately owned rights. Reference herein to any specific commercial product, process, or service by trade name, trademark, manufacturer, or otherwise, does not necessarily constitute or imply its endorsement, recommendation, or favoring by the United States Government or any agency thereof. The views and opinions of authors expressed herein do nol necessarily state or reflect those of the United States Government or any agency thereof. 
ORNL/TM-7091

Distribution Category

$\mathrm{UC}-77$

Contract No. W-7405-eng-26

Engineering Physics Division

\section{ANALYSIS OF FISSION-PRODUCT EFFECTS IN A FAST} MIXED-SPECTRUM REACTOR CONCEPT

J. R. White

T. J. Burns

Date Published - February 1980

NOTICE. This document contains information of a preliminary nature. It is subject to revision or correction and therefore does not represent a finat report.

${ }^{1}$ Computer Sciences Division, UCCND Neither the United Sates Government nor any agency thereof, nor any of their employees, makes any warranty, express or implied, or assumes any legal liability or responsibility for the accuracy.

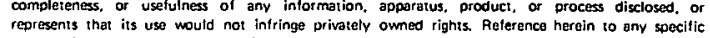

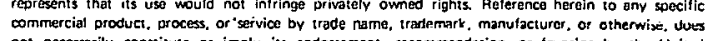
not necessarily conssitute of imply its endorsement. recommendation. or toworing by the United States Governmentrobr any agency thereot. The views and opinions of authors expressed herein do not

OAK RIDGE NATIONAL LABORATORY

Oak Ridge, Tennessee 37830

operated by

UNION CARBIDE CORPORATION

for the

DEPARTMENT OF ENERGY 
THIS PAGE

\section{WAS INTENTIONALLY LEFT BLANK}


CONTENTS

Page No.

Abstract..................................... v

1. Background.................................. 1

2. FMSR Benchmark With and Without Fission Products.......... 2

3. Analysis of Fission Product Cross Sections Versus Burnup...... 8

A. Generation of Nuclide Distributions Versus Burnup....... 8

B. Analysis of Burnup Dependent Nuclide Distributions and Effective Cross Sections...................... 9

C. Conclusions............................ 22

4. Generation of Lumped Fission Product Cross Sections.......... 22

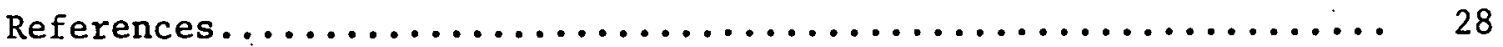




\section{THIS PAGE}

\section{WAS INTENTIONALLY \\ LEFT BLANK}


The Fast Mixed-Spectrum Reactor (FMSR) concept has been proposed by BNL as a means of alleviating certain nonproliferation concerns relating to civilian nuclear power. This breeder reactor concept has been tailored to operate on natural uranium feed (after initial startup), thus eliminating the need for fuel reprocessing. The fissile material required for criticality is produced, in situ, from the fertile feed material. This process requires that large burnup and fluence levels be achievable, which, in turn, necessarily implies that large fission product inventories will exist in the reactor. It was the purpose of this study to investigate the effects of large fission product inventories and to analyze the effect of burnup on fission product nuclide distributions and effective cross sections: In addition, BNL requested that a representative 50-group fission product library be generated for use in FMSR design calculations. Results from the brief investigation of the effects of the large fission product inventory in the FMSR indicated that care needs to be taken when modeling the effects of fission products on reactor performance. They not only have direct reactivity effects, but they also affect power and flux distributions and breeding performance. It was found that deletion of the fission products in a reference FMSR design resulted in a $5.4 \%$ reactivity gain at the beginning-of-life (equilibrium model) and about a $4.2 \%$ gain on the new equilibrium cycle, with the difference being caused by the radial redictribution of the neutron flux.

The effect of burnup on effective fission product cross sections was then analyzed with somewhat surprising results. The final conclusion was that a one-lump fission pronuct model is sufficiently accuratc for 
reliable FMSR design studies. Although a multi-nuclide fission product set which explicitly accounts for the more important chains would be a more accurate representation, the added complexity and cost would outweigh the additional accuracy. It is felt that the uncertainty in the one-lump model is tolerable for preliminary design calculations and probably lies well within the uncertainty of the individual fission product cross sections.

Fina1ly, based on the above conclusione, a 50-group fission product library was generated. The library contains a single fission product lump for each of six spectral regions of a 1-D FMSR model. 


\section{ANALYSIS OF FISSION-PRODUCT EFFECTS IN A FAST}

MIXED-SPECTRUM REACTOR CONCEPT

J. R. White

T. J. Burns

\section{BACKGROUND}

The Fast Mixed-Spectrum Reactor ${ }^{l}$ (FMSR) concept has been proposed by BNL as a means of alleviating certain nonproliferation concerns relating to civilian nuclear power. This breeder reactor concept has been tailored to operate on natural uranium feed (after initial startup), thus eliminating the need for fuel reprocessing. The fissile material required for criticality is produced, in situ, from the fertile feed material. This process requires that large burnup and fluence levels be achievable, which, in turn, necessarily implies that large fission product inventories will exist in the reactor. In fact, approximately $15-20 \%$ of the initially charged heavy metal to the reactor is fissioned during the fuel residence period.

In the early stages of ORNL's preliminary neutronic analysis of the FMSR, ${ }^{2}$ a large discrepancy was noted in the fission product cross sections utilized at BNL relative to ORNL data: This prompted a more detailed analysis of the effects of the large fission product inventory on criticality and the power distribution of the FMSR. It also indicated the need for FMSR-specific cross-sections for the fiosion product nuclldes, as well as for the primary heavy metal nuclides.

The initial lumped fission product data used in the early scoping calculations apparently were derived from ENDF/B-III data (although its ancestry is unverifiable). Due to this latter fact, and the availability 
of ENDF/B-IV data, ${ }^{3}$ a new composite fission product was generated for use in the FMSR calculations. The details of that work are given in ref. 2 .

Although the ENDF/B-IV derived fission product data was considerably more detailed and more reliable, there still remained a question as to the effect of burnup on the final lumped cross sections. A single fission product nuclide density distribution at 56,000 MWD/MTHM was used in the above study. In addition to this concern, BNL requested that they be supplied with a representative fission product library in the LIB-IV 50 -group format.

The following sections discuss the relative imporlance of fisston product data and detail the analysis performed to determine the effects of burnup on the fission product nuclide distributions and effective cross sections. Finally, the actual generation of a representative fission product library for use in BNL calculations is outlined.

\section{FMSR BENCHMARK WITH AND WITHOUT FISSION PRODUCTS}

Before performing a detailed analysis of the burnup effect, a brief study was initiated to determine the importance of the tission product uncertainty in the overall neutronics design of the FMSR. Most of this work is documented in ref. 2. However, a final set of calculations was performed to estimate the upper limit on the reactivity effect of the lumped fission product concentration in the reactor. This was accomplished by setting the initial fission product concentration to zero and disallowing buildup through the fission process. Tables 2.1-2.3 and Figs. 2.1-2.3 contrast the more important neutronic characteristics of the FMSR with 
Table 2.1 First Cycle Comparisons of Fission Product and No Fission Product Cases

\begin{tabular}{lccc} 
1st cycle & $\begin{array}{c}\text { Fission } \\
\text { product }\end{array}$ & $\begin{array}{c}\text { No fission } \\
\text { product }\end{array}$ & \% Diff \\
\hline Keff & & & \\
$\quad$ BOC & 0.979 & 1.032 & 5.41 \\
EOC & 1.003 & 1.054 & 5.08 \\
Breeding ratio & & & \\
BOC & 1.662 & 1.608 & -3.25 \\
\hline
\end{tabular}

Table 2.2 Equilibrium Cycle Comparison of Fission Product and No Fission Product Cases

\begin{tabular}{lccc} 
8th cycle & $\begin{array}{c}\text { Fission } \\
\text { product }\end{array}$ & $\begin{array}{c}\text { No fission } \\
\text { product }\end{array}$ & $\%$ Diff \\
\hline Keff & & & \\
BOC & 0.967 & 1.008 & 4.24 \\
EOC & 0.989 & 1.032 & 4.35 \\
Breeding ratio & & & -1.70 \\
BOC & 1.701 & 1.672 & \\
\hline
\end{tabular}


Table 2.3 Ictal Nuclide Reaction Rates at EOL*

\begin{tabular}{|c|c|c|c|c|c|c|}
\hline \multirow[b]{2}{*}{ Nuclide } & \multicolumn{3}{|c|}{ Reference } & \multicolumn{3}{|c|}{ No fission products } \\
\hline & Absorption & Capture & $\begin{array}{l}\text { Neutron } \\
\text { production }\end{array}$ & Absorption & Capture & $\begin{array}{l}\text { Neutron } \\
\text { production }\end{array}$ \\
\hline${ }^{235} \mathrm{U}$ & $1.885-2$ & $4.464-3$ & $3.522-2$ & $2.143-2$ & $5.256-3$ & $3.954-2$ \\
\hline${ }^{238} \mathrm{U}$ & $5.501-1$ & $4.754-1$ & 2. $(100-1$ & $5.697-1$ & $4.939-1$ & $2.111-1$ \\
\hline${ }^{239} \mathrm{Pu}$ & $2.890-1$ & $4.803-2$ & $7 .(178-1$ & $3.135-1$ & $5.762-2$ & $7.510-1$ \\
\hline${ }^{240} \mathrm{Pu}$ & $1.739-2$ & $1.167-2$ & $1.753-2$ & $2.393-2$ & $1.789-2$ & $1.850-2$ \\
\hline $24 \mathrm{l} \mathrm{Pu}$ & $\dot{4} .118-3$ & $5.911-4$ & 1. (151-2 & $4.736-3$ & $7.294-4$ & $1.192-2$ \\
\hline${ }^{242} \mathrm{Pu}$ & $1.587-4$ & $9.771-5$ & $1.847-4$ & $2.352-4$ & $1.716-4$ & $1.946-4$ \\
\hline $\mathrm{Be} 9 * *$ & $-3.708-3$ & $-3.708-3$ & - & $-5.407-3$ & $-5.407-3$ & - \\
\hline Struc & $\Xi .005-2$ & $5.005-2$ & - & $5.755-2$ & $5.755-2$ & - \\
\hline Fissp & $\Xi .915-2$ & $5.915-2$ & - & - & - & - \\
\hline Total & $\Xi .851-1$ & $6.457-1$ & $9.793-1$ & $9.857-1$ & $6.277-1$ & 1.032 \\
\hline
\end{tabular}

*Normalized to 1 neutron lost (absorption and leakage).

$* *$ Negative values reflect the inclusian of th.e $(n, 2 n)$ reaction. 


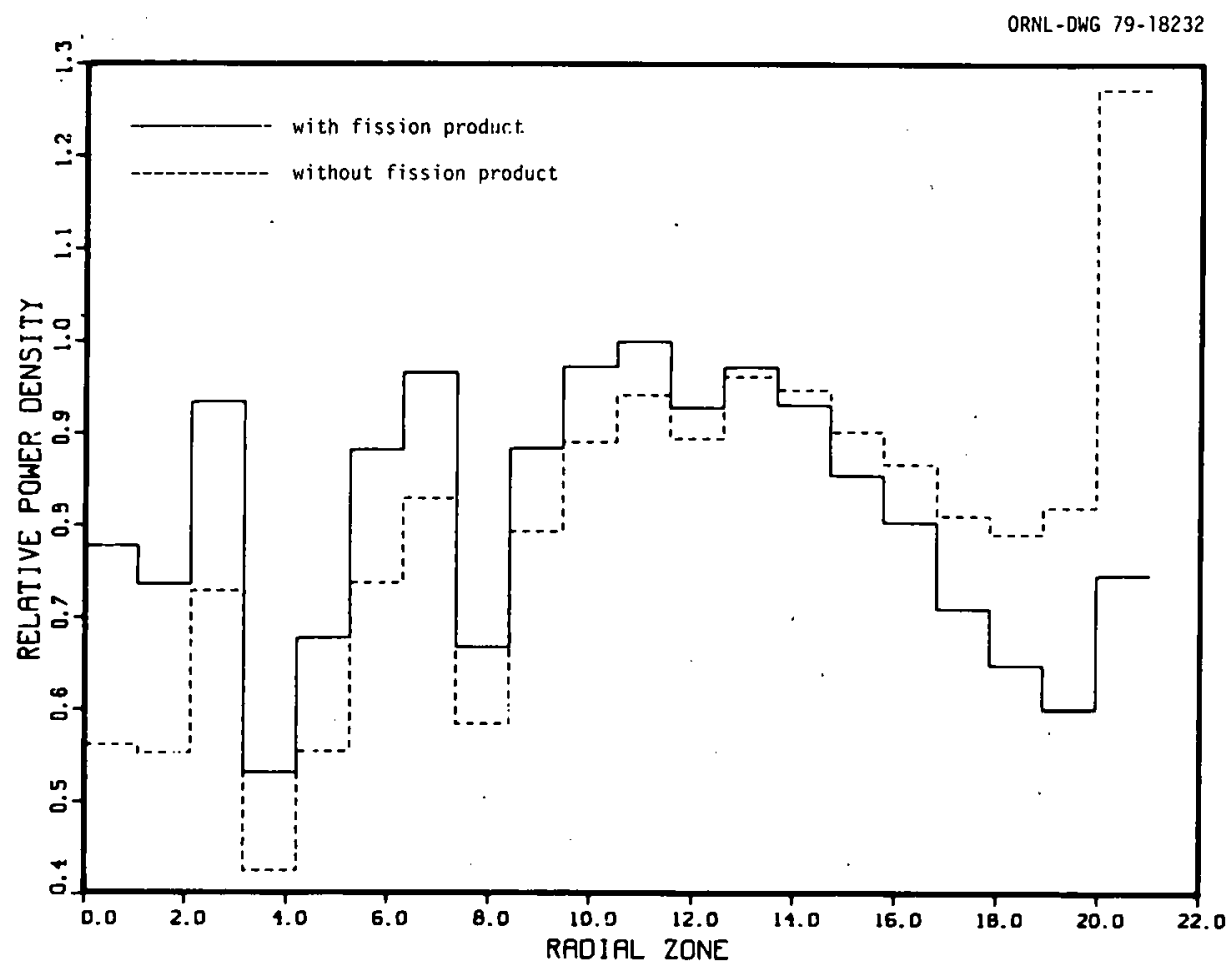

Fig. 2.1. Radial power distribution for cases with and without fission products (see ref, 2 for model description).

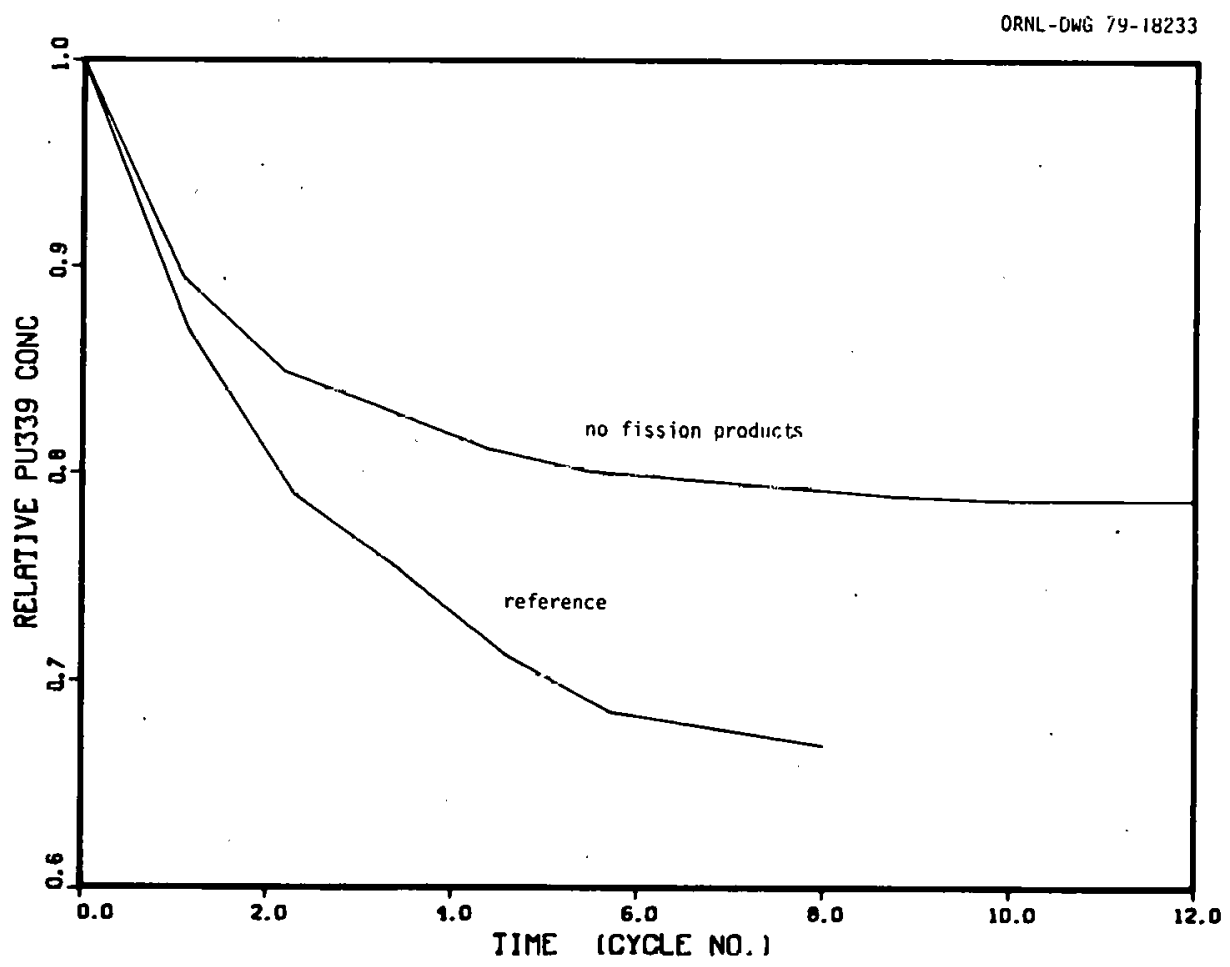

Fig. 2.2. Zone $14{ }^{239} \mathrm{Pu}$ concentration for reference and no fission product cases (see ref. 2 for model description). 


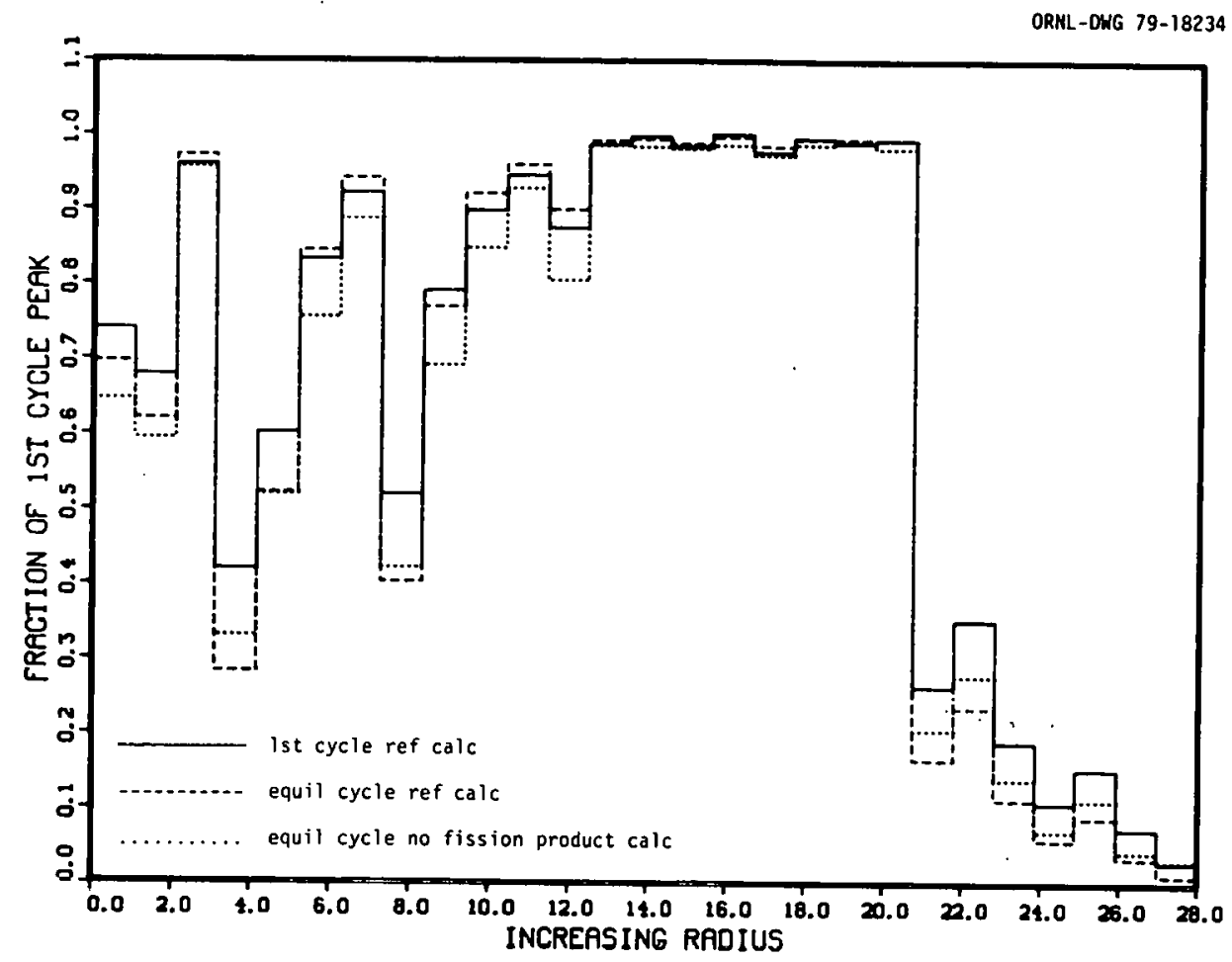

Fig. 2.3. ${ }^{239} \mathrm{Pu}$ distribution for reference and no fission product cases (see ref. 2 for model description).

and without consideration of the equilibrium cycle fission product inventory. Table 2.1 and 2.2 glve comparisons of reactivity and breeding ratio for the first and equilibrium cycles, respectivcly. In addition, the overall neutron balance at the beginning-of-life (BOL) for the two cases are contrasted in Table 2.3. As can be seen, the deletion of the fission products at the BOL resulted in a $5.4 \%$ reactivity gain. However, on the equilibrium cycle the reactivity increase relative to the reference calculation with tission products was only abuut $4.2 \%$. The reason for this difference is that the fission product concentration was not uniform in the reference model. Therefore, elimination of the total fission product inventory resulted in a radial redistibution of the power density which, in turn, caused a redistribution of the equilibrium ${ }^{239} \mathrm{Pu}$ concentration in the reactor. 
These effects are displayed graphically in Figs. 2.1-2.3. Figure 2.1 shows a decrease in the relative power production in the central regions and a large jump in power density near the fast core/moderator region interface. Since the ${ }^{239} \mathrm{Pu}$ distribution is unchanged at the BOL, this power shift is also indicative of the flux redistribution due to the absence of the fission products. Thus, there will be a decrease in the ${ }^{239} \mathrm{Pu}$ buildup rate in the center of the core and an increase in $239^{\mathrm{Pu}}$ production toward the outer moderated regions.

The effect of this flux shift over several depletion cycles can be seen in Figs. 2.2 and 2.3. The first of these shows the relative $239 \mathrm{p}_{1}$ concentration versus time in the first moderator region. As can be seen, the equilibrium concentration is considerably increased for the no fission product case relative to the reference calculation. Since ${ }^{239} \mathrm{Pu}$ from this region is shuffled into the fast core, an increase there should also be expected. This can be seen in Fig. 2.3 where the BOL and equilibrium ${ }^{239} \mathrm{Pu}$ distributions are given. However, this initial increase is more than offset by the decreased breeding performance of the central fast core for the no fission product case. From Fig. 2.3 one sees that abuul four cycles residence time in this region is required to reduce the ${ }^{239} \mathrm{Pu}$ concentration levels below that obtained in the reference calculation.

Results from this brief investigation of the effects of the large fission product inventory in the FMSR indicate that care needs to be taken when modeling the effects of fission' products on reactor performance. They not only have direct reactivity effects, but they also affect power and flux distributions and breeding performance. However, it must 
be remembered that the above study looked at the extreme case of a $100 \%$ decrease in the fission product concentration (or cross section). The uncertainty associated with the lumped fission product cross section utilized in the reference calculation is more likely on the order of 1020\%. Thus, although still important, the changes from the reference state would be greatly reduced from those observed in this study.

\section{ANALYSIS OF FISSION PRODUCT CROSS SECTJONS VERSUS BURNUP}

A. Generation of Nuclide Distributions Versus Burnup

The number densities required for the generation of the burnupdependent lumped fission product cross sections were calculated using the ORIGEN $^{5}$ computer code. An equilibrium cycle calculation for the "benchmark" refueling and shuffling strategy was performed using the CITATION $^{6}$ code. The 34 cycle power history of a single batch was then input into ORIGEN, together with the appropriate initial heavy metal number densities, to determine the r1me-dependent distribution of individual fission product nuclides. Since ORIGEN tracks a total of 831 fission products, an edit of the 181 fission product nuclides for which multigroup data exists was performed to address the adequacy of the 181 representation. For all burnups, the 181 uuclides repregent better than $99.8 \%$ of the total fission products.

It should be noted, however, that the use of the ORIGEN code does represent a degree of approximation. The ORIGEN code utilizes a zerodimensional one-group model for the configuration in question. Four basic libraries were available; LWR, HTGR, LMFBR, and MSR. The cross sections in these libraries have been collapsed using spectra typical of 
the reactors specified. The basic library utilized for this study was the LMFBR library, since it was judged to be more representative of the FMSR than the others. It must be noted, however, that an LMFBR spectrum is harder than that of the FMSR's moderated region and softer than that in the fast core region. Thus, the number densities determined via ORIGEN are subject to some spectral uncertainty. However, this uncertainty is probably of the order of the uncertainty inherent in the basic cross sections themselves.

B. Analysis of Burnup Dependent Nuclide Distributions and Effective Cross Sections

An analysis addressing the question of burnup dependent cross sections was performed employing the fission product density distributions determined in the ORIGEN calculation described above. The goals of the analysis were to determine the influence of burnup on an effective fission product cross section and to determine the best way to efficiently and accurately model this dependence.

The data available for the analysis were the density distributions versus burnup and a 126 yroup fission product library consisting of 181 individual. isotopes. To make the analysis more manageable only the eleven discrete burnups listed in Table 3.1 were utilized. In addition, the cross sections were reduced to the 1-group level using two different spectra representative of the fast and moderated regions of the reference FMSR. Figure 3.1 displays the spectra used in the analysis and also emphasizes the need for spatially dependent cross sections for accurate FMSR studies due to the large variations in the region spectra. The next step was to calculate the 1-group macroscopic absorption cross 


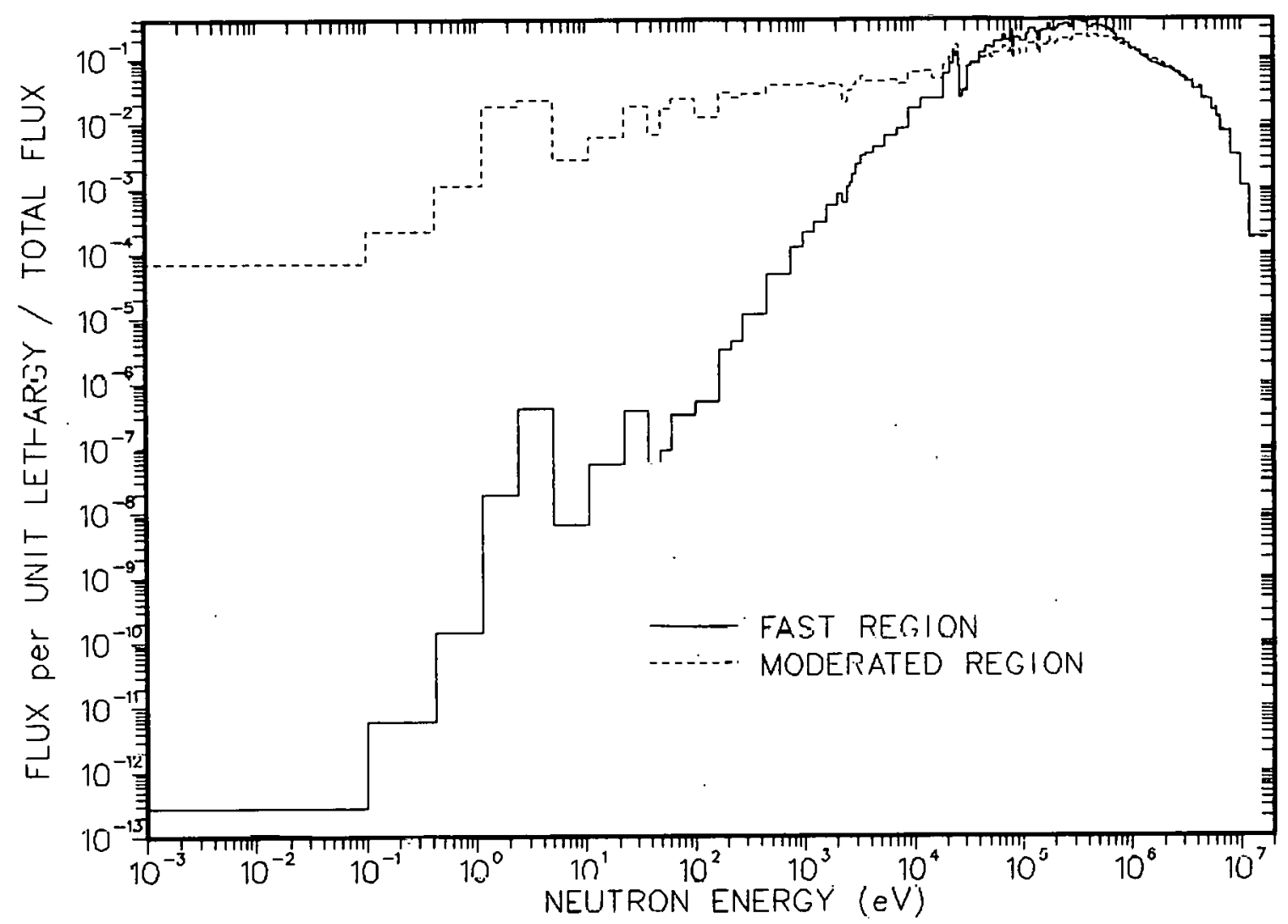

F1g. 3.1. Spectra used to collapse fisslun pluduct eroso occtions.

section of the 181 individual fission products at each burnup interval for both spectra shown in Fig. 3.1. These reaction rates were then sorted in order of decreasing importance. In th1s manner the most important nuclides could be identified. Tables 3.2 and 3.3 1ist the ten most importanl uuclides at three different hurnupc in the fast and moderated regions, respectively. Also tabulated are the percent of the total reaction rate that each nuclide represents.

Several important observations can be made from the data presented in Tables 3.2 and 3.3. Most striking, of course, is the very large importance associated with SM-149 in the moderated flux region. This 
Table 3.1 Discrete Burnups Used in the Present Analysis

\begin{tabular}{cccc}
\hline Index & $\begin{array}{c}\text { Refueling } \\
\text { interval }\end{array}$ & $\begin{array}{c}\text { Depletion } \\
\text { time } \\
\text { (days) }\end{array}$ & $\begin{array}{c}\text { Burnup } \\
\text { (MWD/MTHM) }\end{array}$ \\
\hline 1 & 1 & 185 & 22.7 \\
2 & 4 & 740 & 113.7 \\
3 & 8 & 1480 & 616.9 \\
4 & 11 & 2035 & 2240 \\
5 & 14 & 2590 & 10163 \\
6 & 16 & 2960 & 22950 \\
7 & 20 & 3700 & 55314 \\
8 & 23 & 4255 & 82749 \\
9 & 26 & 4810 & 111844 \\
10 & 30 & 5550 & 141467 \\
11 & 34 & 6290 & 170812 \\
\hline
\end{tabular}

one nuclide accounts for approximately $45 \%$ of all neutron losses to the fission products. Just as important, however, is the fact that in the fast region, SM-149 is only of moderate importance at low burnups and accounts for less than $3 \%$ of the total absorptions at very large burnups.

Taking this comparison one step further, one sees that many of the nuclides important in the moderated region are not even included in the top ten nuclides for the fast region. For example, SM-151, XE-135, and CS-135 which contribute considerably in the moderated region are not even tabulated in Table 3.2. Another important area needing consideration is the relative importance of various nuclides as a function of burnup. 
Table 3.2 Importarce-Razked Nuclides in Fast Flux Region

\begin{tabular}{|c|c|c|c|c|c|c|}
\hline \multirow{2}{*}{$\begin{array}{l}\text { Burnup = } \\
\text { Index } i\end{array}$} & \multicolumn{2}{|c|}{$10163 \mathrm{MWD} / \mathrm{MTHM}$} & \multicolumn{2}{|c|}{$82747 \mathrm{MWD} / \mathrm{MTHM}$} & \multicolumn{2}{|c|}{$170812 \mathrm{MWD} / \mathrm{MTHM}$} \\
\hline & Nuclide & $\begin{array}{c}\sum a i / \sum a t \\
(\%)\end{array}$ & Nuclide & $\begin{array}{c}\sum a i / \Sigma a t \\
(\%)\end{array}$ & Nuclide & $\begin{array}{c}\sum a i / \Sigma a t \\
(\%)\end{array}$ \\
\hline 1 & RH-103 & 9.88 & $\mathrm{RH}-103$ & 10.95 & $\mathrm{RH}-103$ & 11.77 \\
\hline 2 & RU-101 & 8.85 & PJ-105 & 9.20 & PD-105 & 8.96 \\
\hline 3 & PL-105 & 8.78 & $R^{-} J-101$ & 8.05 & RU-101 & 7.47 \\
\hline .4 & CS-133 & 7.01 & Cร-133 & 6.77 & $\mathrm{CS}-133$ & 6.63 \\
\hline 5 & $\mathrm{TC}-99$ & 6.27 & $T 2-99$ & 5.87 & TC-99 & 5.72 \\
\hline 6 & SN-149 & 4.33 & SY-149 & 3.74 & RU-102 & 3.80 \\
\hline 7 & $P K-147$ & 3.92 & PD-107 & 3.68 & PD -107 & 3.77 \\
\hline 8 & $M C-97$ & 3.56 & $\mathrm{RU}-102$ & 3.59 & MO-97 & 3.46 \\
\hline 9 & $\mathrm{RL}^{-}-102$ & 3.38 & $\mathrm{MD}-97$ & 3.30 & MO-95 & 3.22 \\
\hline 10 & $N I-143$ & 2.90 & $\mathrm{MD}-95$ & 2.87 & ND-143 & 2.94 \\
\hline Total & & 58.88 & & 58.02 & & 57.74 \\
\hline
\end{tabular}


Table 3.3 Importance-Ranked Nuclides in Moderated Flux Region

\begin{tabular}{|c|c|c|c|c|c|c|}
\hline \multirow{2}{*}{$\begin{array}{l}\text { Burnup }= \\
\text { Index } i\end{array}$} & \multicolumn{2}{|c|}{$10163 \mathrm{MWD} / \mathrm{MTHM}$} & \multicolumn{2}{|c|}{$82747 \mathrm{MWD} / \mathrm{MTHM}$} & \multicolumn{2}{|c|}{$170812 \mathrm{MWD} / \mathrm{MTHM}$} \\
\hline & Nuclide & $\begin{array}{c}\sum a i / \Sigma a t \\
(\%)\end{array}$ & Nuclide & $\begin{array}{c}\sum a i / \Sigma a t \\
(\%)\end{array}$ & Nuclide & $\begin{array}{c}\sum a i / \sum a t \\
(\%)\end{array}$ \\
\hline 1 & $S M-149$ & 47.67 & SM-149 & 45.75 & SM-149 & 45.88 \\
\hline 2 & SM-151 & 8.81 & SM-151 & 8.96 & $S M-151$ & 8.89 \\
\hline 3 & $X E-135$ & 4.80 & $\mathrm{CS}-135$ & 3.64 & $\mathrm{CS}-135$ & 3.98 \\
\hline 4 & $P M-147$ & 3.66 & $X E-135$ & 2.85 & ND-143 & 2.85 \\
\hline 5 & $\mathrm{CS}-135$ & 3.25 & ND-143 & 2.74 & PD-105 & 2.77 \\
\hline 6 & $N D-143$ & 2.72 & $P D-105$ & 2.63 & TC-99 & 2.34 \\
\hline 7 & $P[-105$ & 2.26 & PM-147 & 2.57 & $\mathrm{RH}-103$ & 2.14 \\
\hline 8 & TC-99 & 2.13 & TC-99 & 2.22 & RU-.101 & 2.12 \\
\hline 9 & RU-101 & 2.08 & $E U-155$ & 2.16 & PD-107 & 2.07 \\
\hline 10 & $E \dot{U}-155$ & 1.71 & RU-101 & 2.11 & EU-155 & 2.07 \\
\hline Total & & 79.09 & & .75 .63 & & 75.11 \\
\hline
\end{tabular}


For example, in the moderated region XE-135 accounts for $4.8 \%$ of the total absorption at low burnups, $2.8 \%$ at burnups around $80,000 \mathrm{MWD} / \mathrm{MTHM}$, and only about $1.0 \%$ at $170,000 \mathrm{MWD} / \mathrm{MTHM}$. The reason for this is that the XE-135 concentration reaches an equilibrium level depending on the flux level relatively quickly; but other isotopes, like CS-135, are nonsaturating and, therefore, their concentrations increase approximately linearly with burnup.

A single lumped fission product palr absuption erosa ocction versus burnup was then calculated using:

$$
\bar{\sigma}_{a b}=\frac{\sum_{i}\left(N_{i} \sigma_{a i}\right)_{b}}{\sum_{i}\left(N_{i}\right)_{b}} * 2.0,
$$

where the subscript $b$ refers to a specific burnup. Results of this calculation using both the fast and moderated spectra are displayed in Fig. 3.2 and 3.3 , respectively. The effective lumped cross section 1 s essentially constant with burnup in the fast reglone of the EMSR. The moderated region's cross section, however, shows a fairly linear decrease with burnup. The slope of this line is quite small and gives a $13 \%$ decrease in the lumped fission product cross section over the range of about 40,000 to $170,000 \mathrm{MWD} / \mathrm{MTHM}$.

This constant relaclonthlp of the renga acctione with burnup is emphasized in Figs. 3.4 and 3.5. The macroscopic effective cross section and total fission product concentration is plotted versus burnup. The macroscopic cross section is given by:

$$
\Sigma_{\mathrm{ab}}=\mathrm{N}_{\mathrm{Tb}} \bar{\sigma}_{\mathrm{ab}}
$$

where

$$
\mathrm{N}_{\mathrm{Tb}}=\sum_{i}\left(\mathrm{~N}_{i}\right)_{\mathrm{b}}
$$




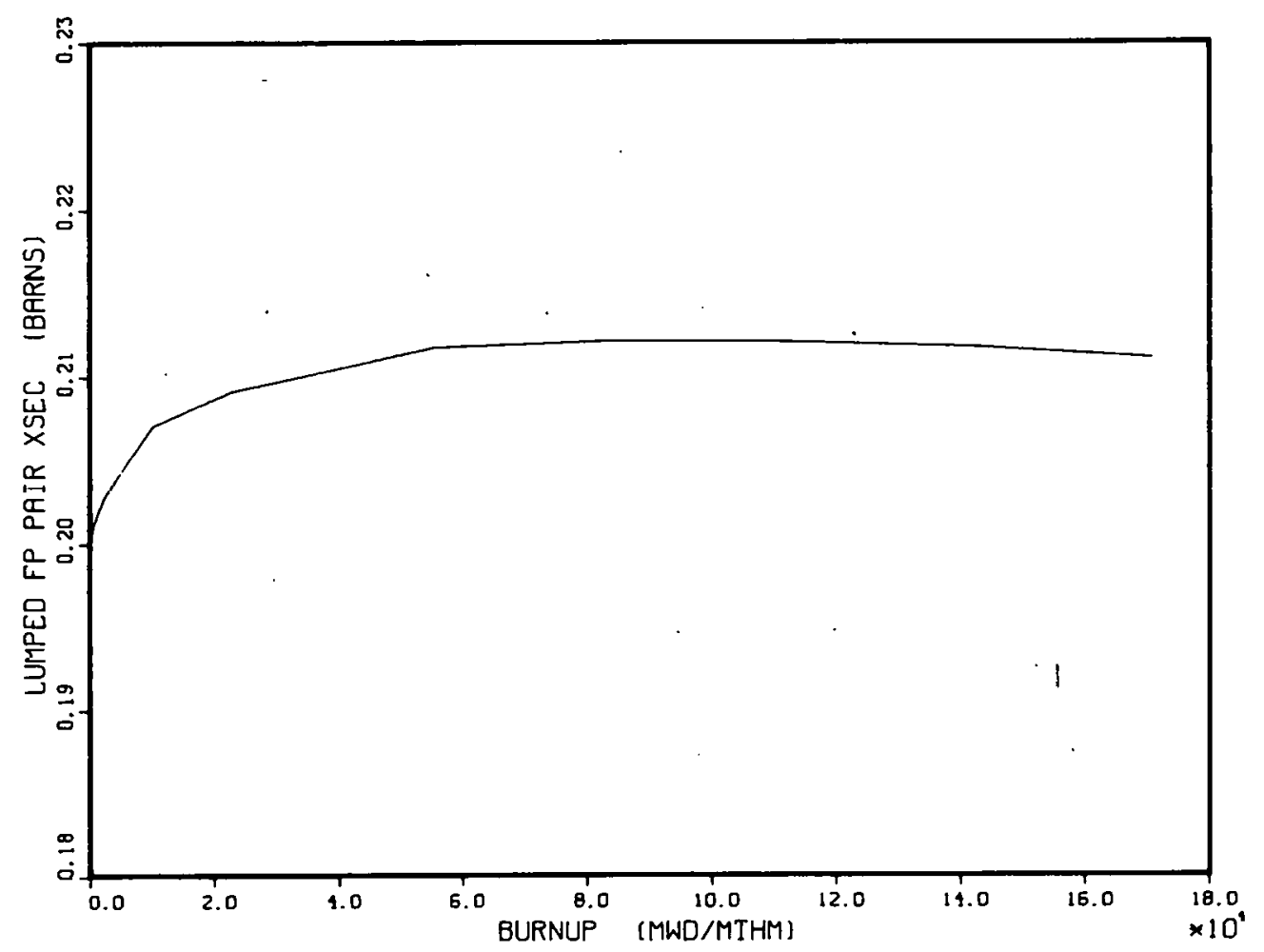

Fig. 3.2. 1-group absorption cross section versus burnup for fast region spectra.

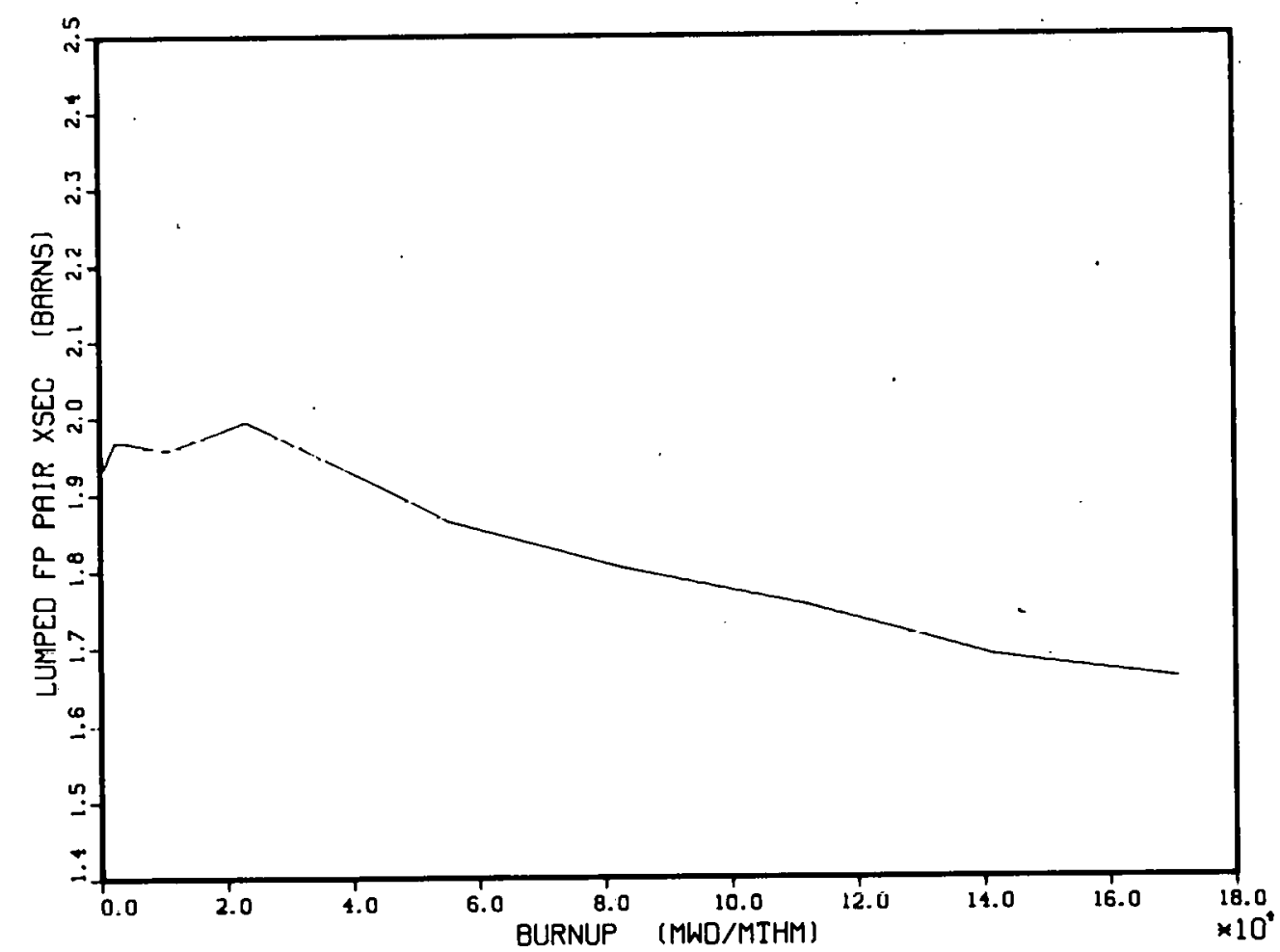

Fig. 3.3. 1-group absorption cross section versus burnup for moderated region spectra. 


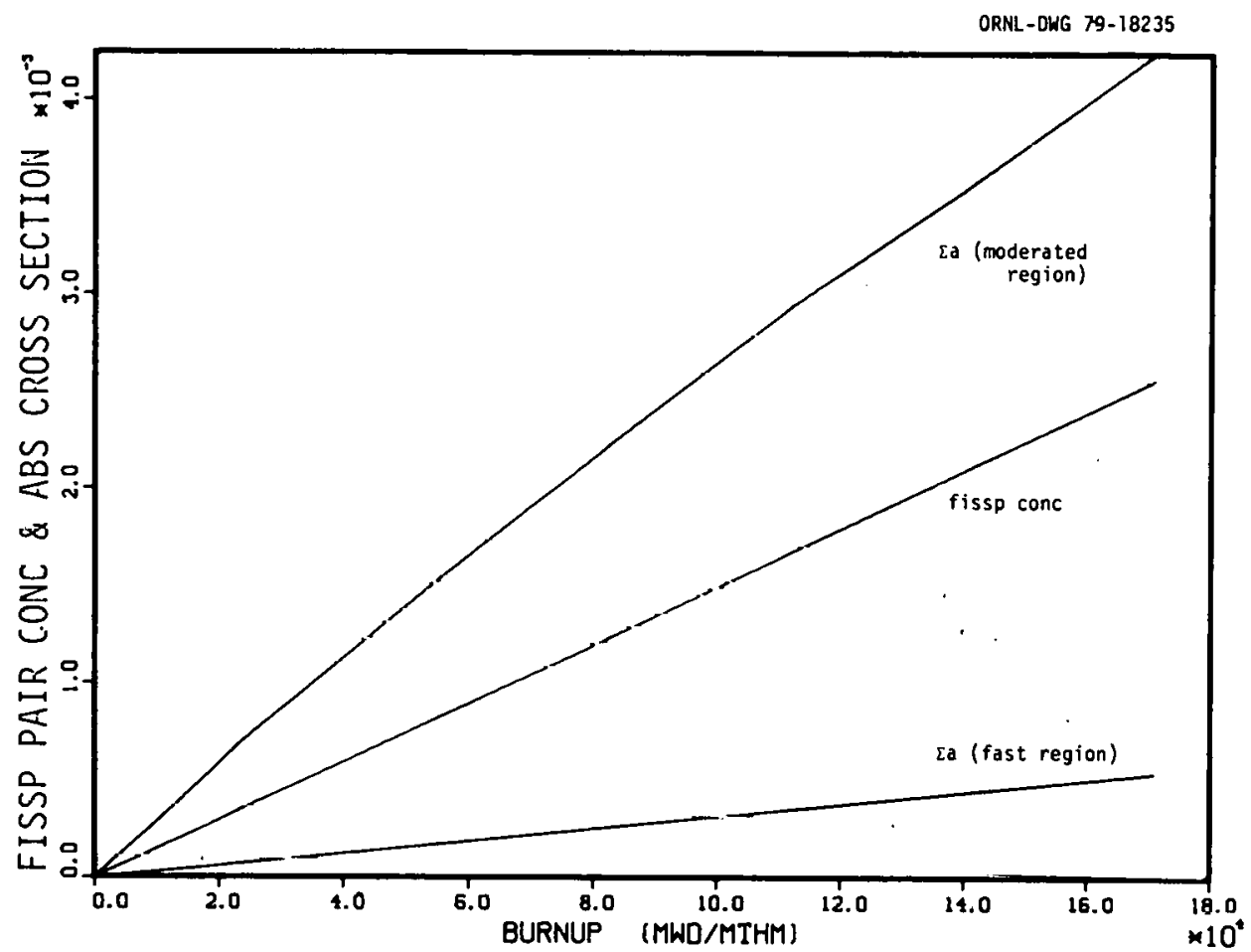

Fig. 3.4. Lumped fission product concentration and absorption rate versus burnup.

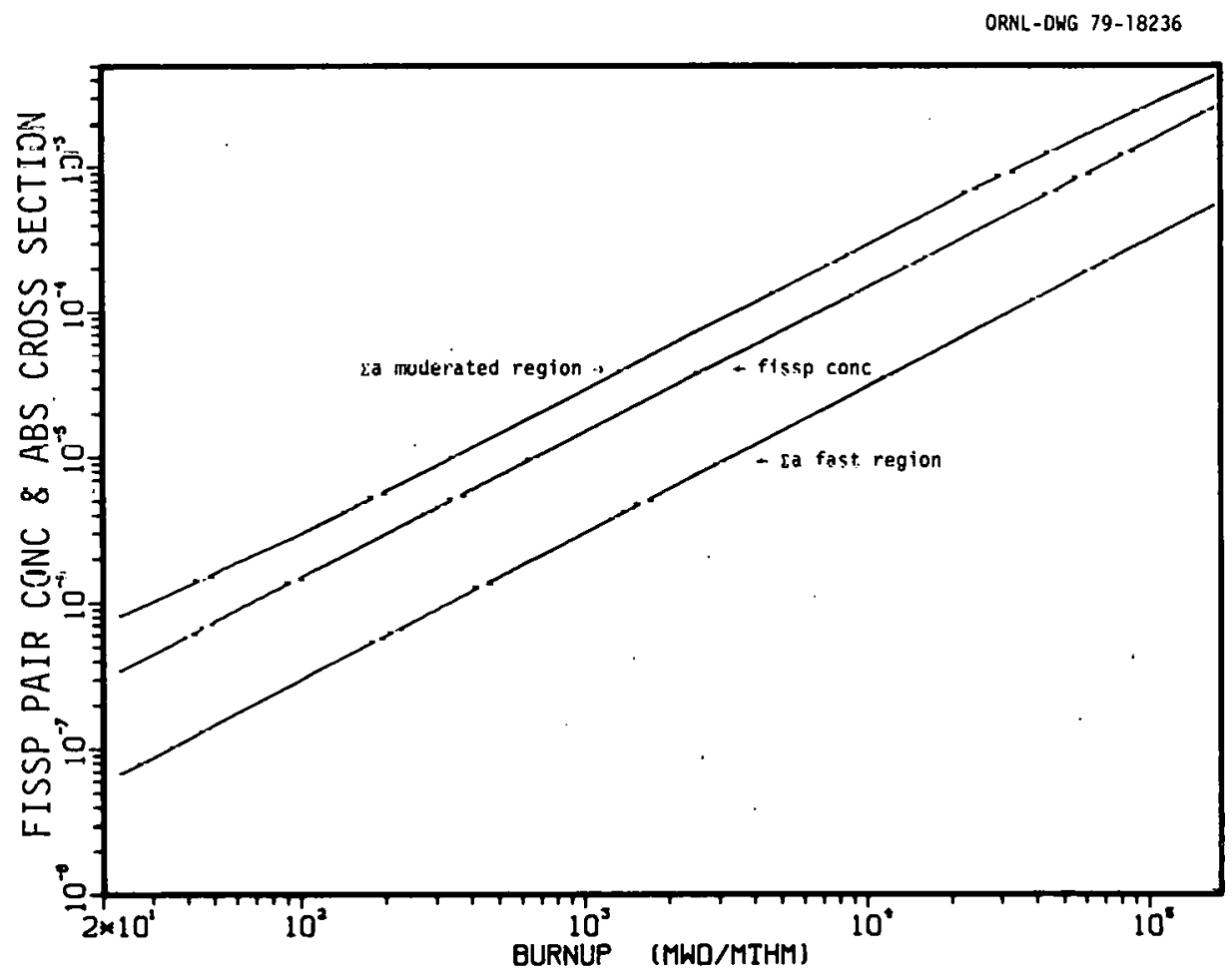

Fig. 3.5. Lumped fission product cuncentration and absorption rate versus burnup plotted on a log-log scale. 
Figs. 3.4 and 3.5 display the same data in slightly different form. The key point to note is the near linear relationship with burnup of both the fast and moderated region effective cross sections.

At this point in the study it was suggested that two lumped cross sections be utilized, one representing the more important odd atomic numbered isotopes and one representing the even isotopes. In this way one might be able to account for the neutron capture of an odd isotope going to an even isotope. This might model the effect observed in Fig. 3.3.

This suggestion was investigated further in the following manner. First a plot of the fission product distribution as a function of the atomic number was drawn for different burnups. Fig. 3.6 shows one such plot. A shift in the distribution to higher atomic number with burnup is clearly apparent. The concentrations for the even and odd isotopes were then summed separately and plotted as a function of burnup in Fig. 3.7. At zero burnup the normalized density of both the even and odd isotopes were nearly unity. The normalized even isotope density increased linearly with burnup with about a $5 \%$ increase over the 170,000 MWD/MTHM burn. Obviously, a corresponding decrease in the odd atomic number nuclides was observed. This odd-even transmutation effect, therefore, has a maximum effect of only $3-4 \%$ on the macroscopic absorption rate. In addition, if the reference burnup for a 1-lump model was taken in the center of the burn, there would be only a $\pm 2 \%$ variation from the reference.

Individual odd and even microscopic lumped cross sections also were generated so that their behavior with burnup could be investigated. Figures 3.8 and 3.9 display the results of this exercise. The conclusion 


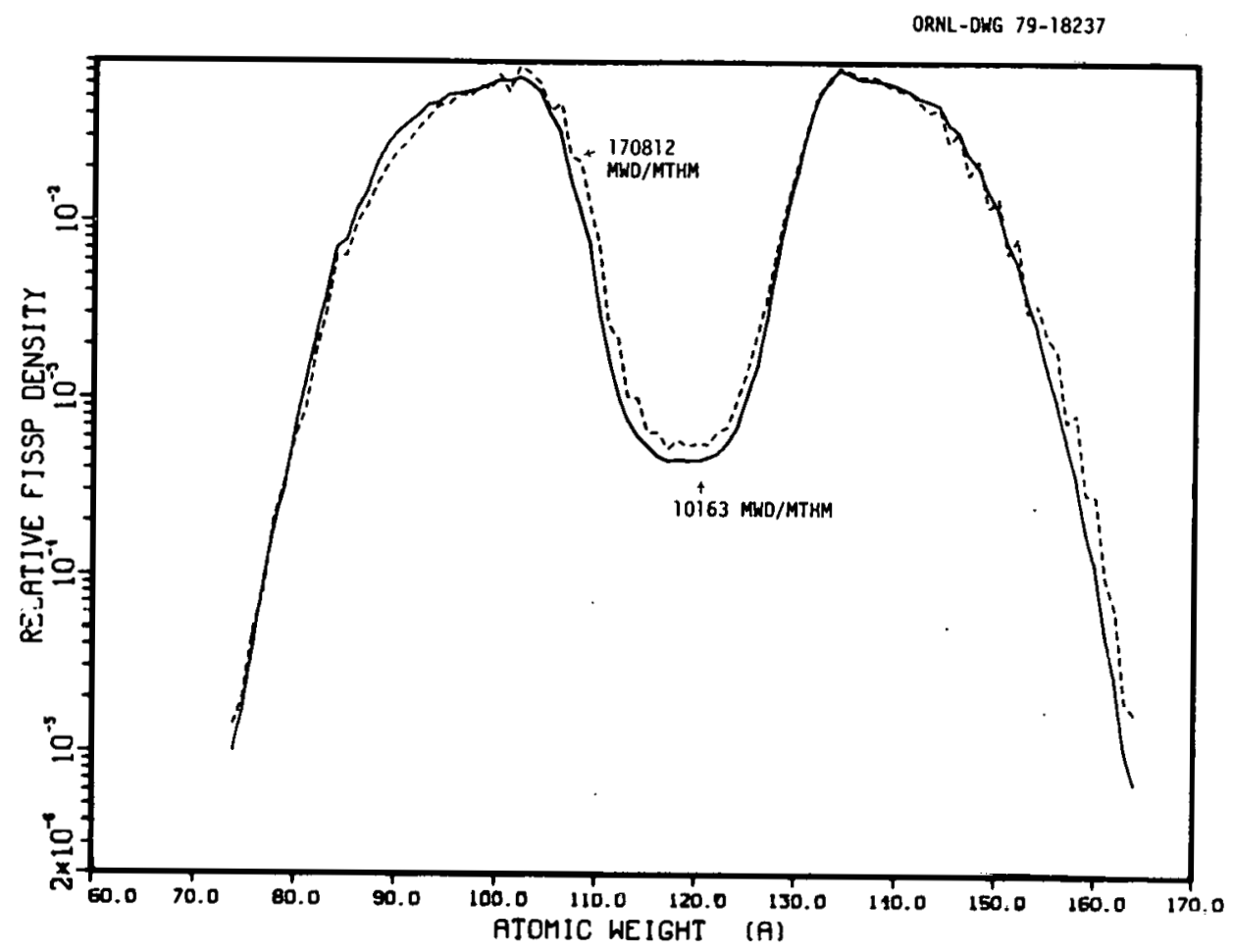

Fig. 3.6. Fission product density versus atomic number as a function of burnup.

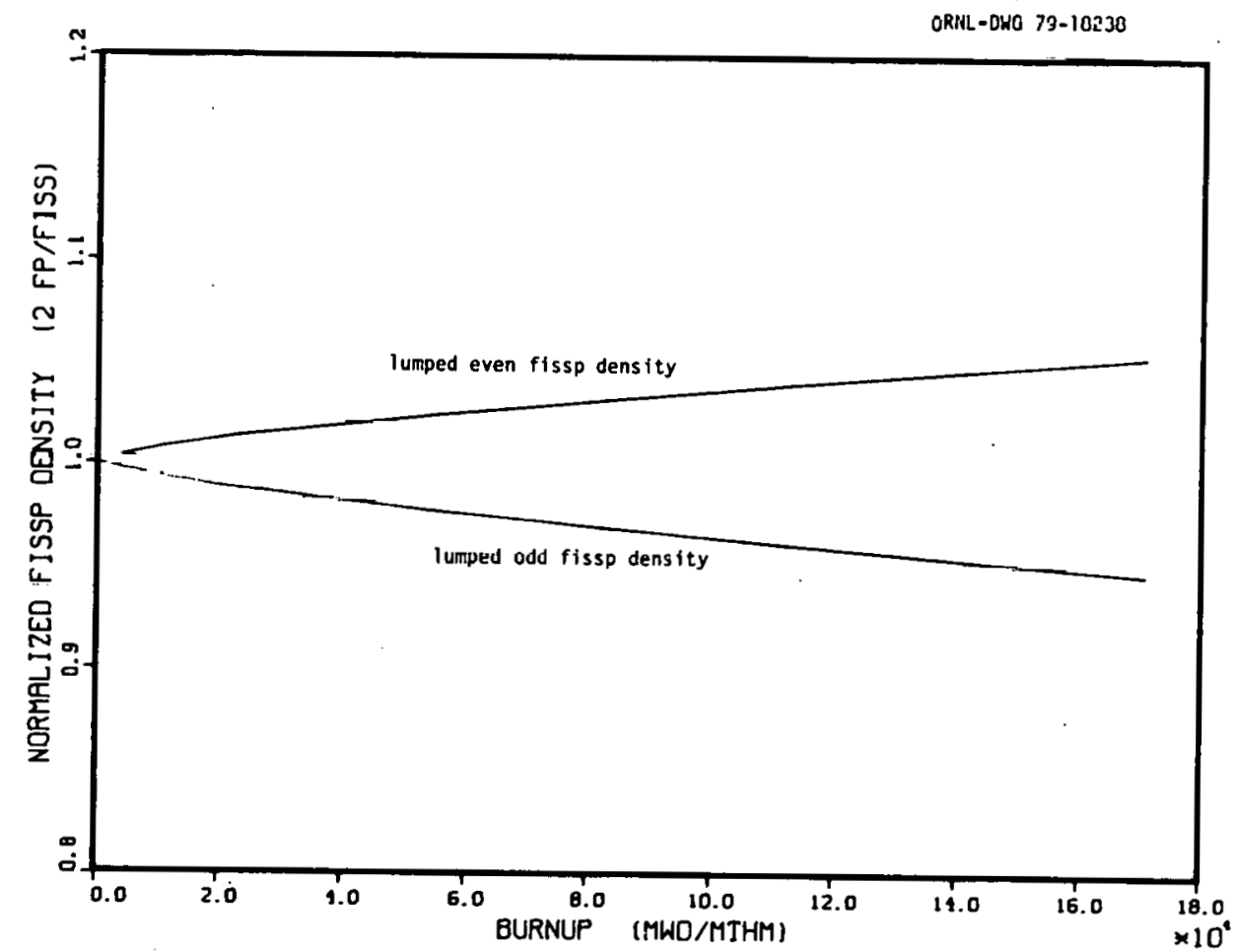
burnup.

Fig. 3.7. Even and odd lumped fisston product densities versus 


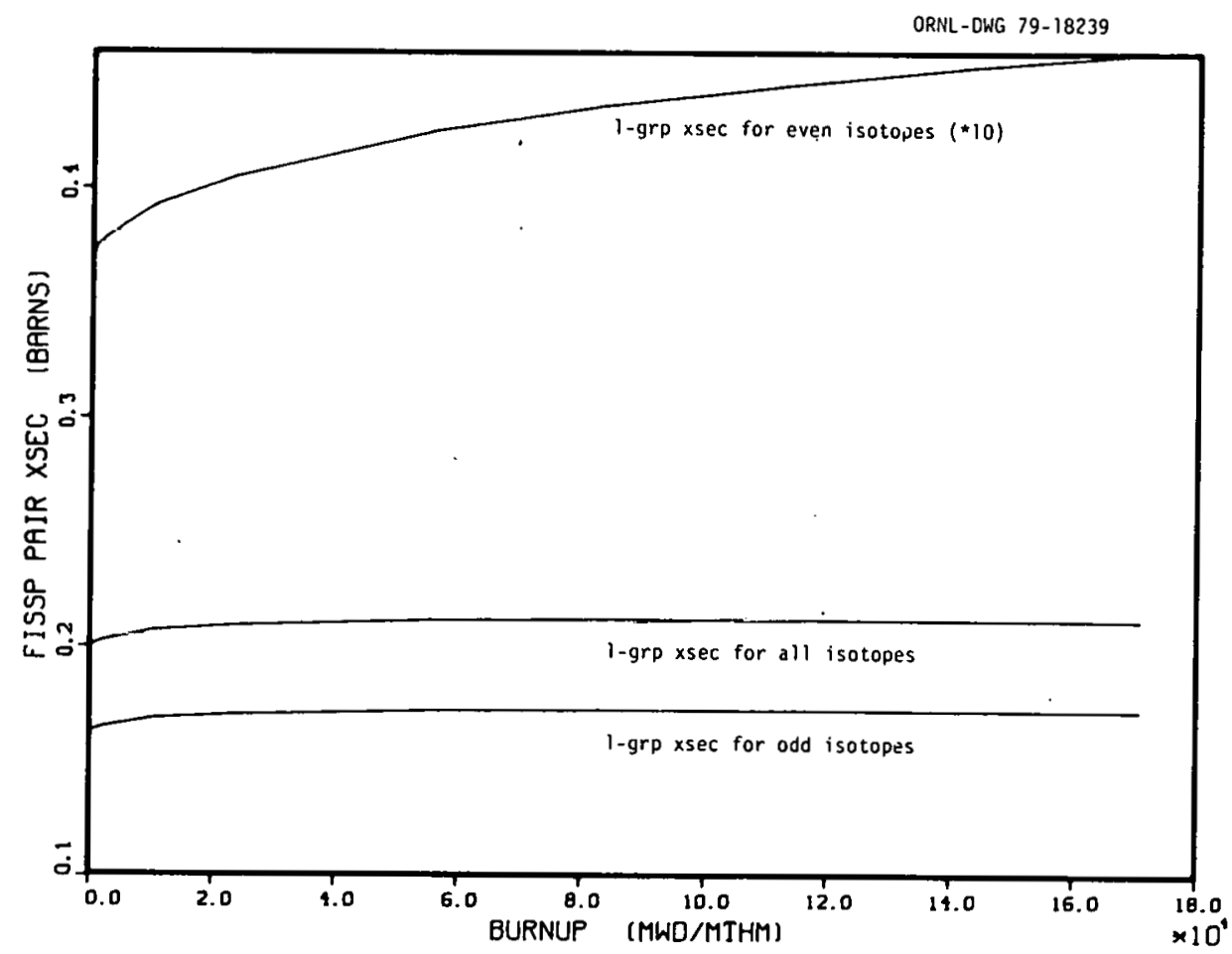

Fig. 3.8. Even and odd lumped absorption cross sections versus burnup for fast region spectra.

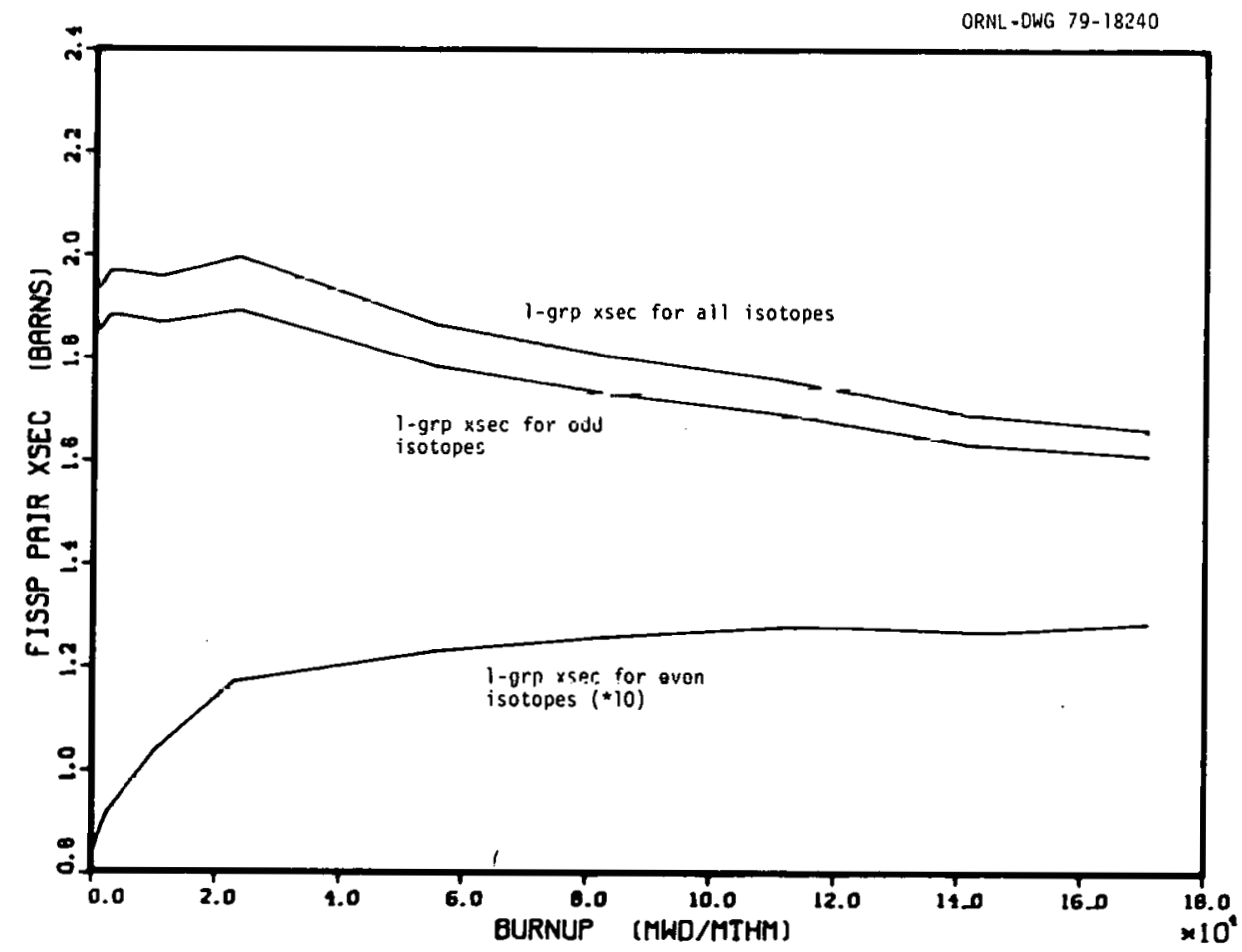

Fig. 3.9. Even and odd lumped absorption cross sections versus burnup for moderated region spectra. 
is that since the even isotope's contribution to the total microscopic absorption cross section is small, the one lumped cross section essentially has the same shape as the odd isotope cross section. Thus, the variation of the nuclide distribution within the odd lump is the major cause of the variation of the one lumped cross section with burnup.

This observation is more apparent in Figs. 3.10 and 3.11. Through examination of the important nuclide concentrations it was determined that, in the moderated region at least, ${ }^{135} \mathrm{Xe},{ }^{147} \mathrm{Pm}$, and $1^{149} \mathrm{Sm}$ were the key isotopes. These three isotopes' variation with burnup contributed to much of the cross section variation observed in Fig. 3.3. Therefore, an analysis was performed on a partial lumped fission product that excluded the nulcides in the ${ }^{135} \mathrm{Xe},{ }^{147} \mathrm{Pm}$, and ${ }^{149} \mathrm{Sm}$ chains. The chains excluded were:

$$
135 \mathrm{I}+135 \mathrm{Xe} \rightarrow 135 \mathrm{Cs}
$$

and

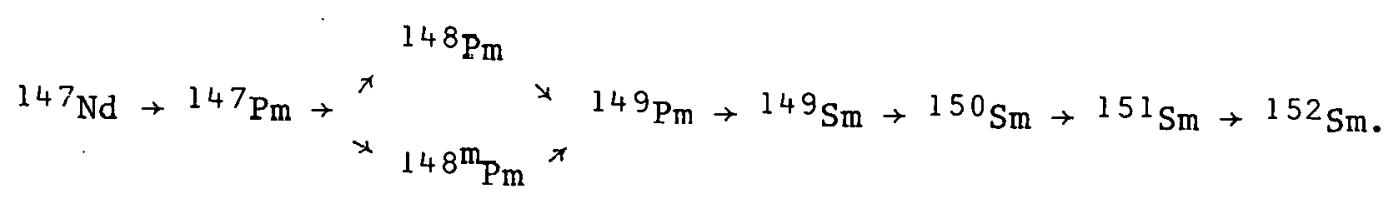

Therefore, there was a total of 13 fission product nuclides, 3 from the Xe chain, 9 from the PII and Sm chain, and 1 partial lumped fission product. It is the variation of this partial lumped cross section with burnup that is displayed in Figs. 3.10 and 3.11. After an Inftial transient period, the partial lumped cross section is relatively constant with burnup in both fast and moderated flux spectra. Thus, this indicates that it is the variation of the $\mathrm{Xe}, \mathrm{Pm}$, and $\mathrm{Sm}$ chains that account for most of the variation of the one lumped fission product pair cross section (in the moderated region). 


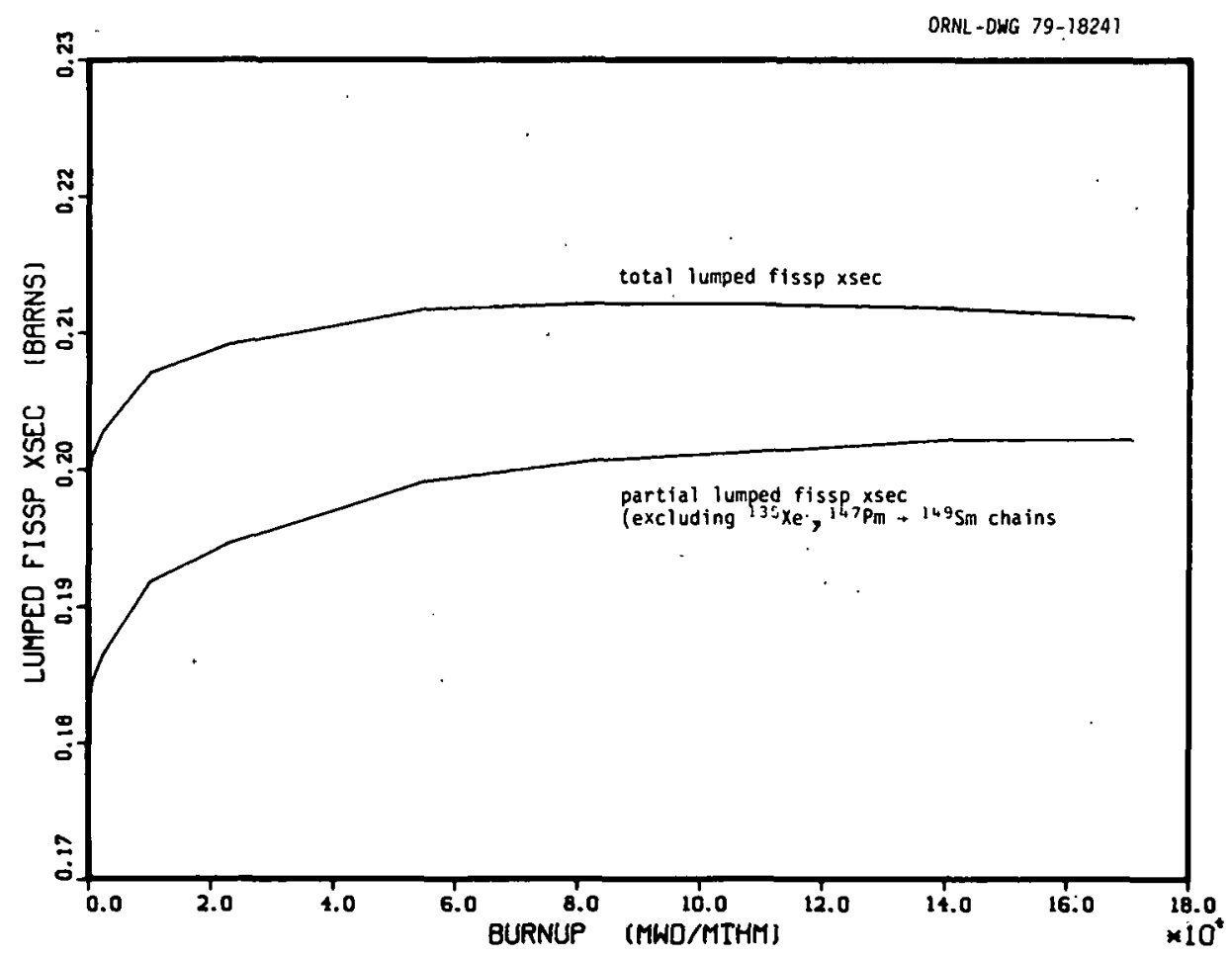

Fig. 3.10. Partial lumped fission product cross section versus burnup for fast region spectra.

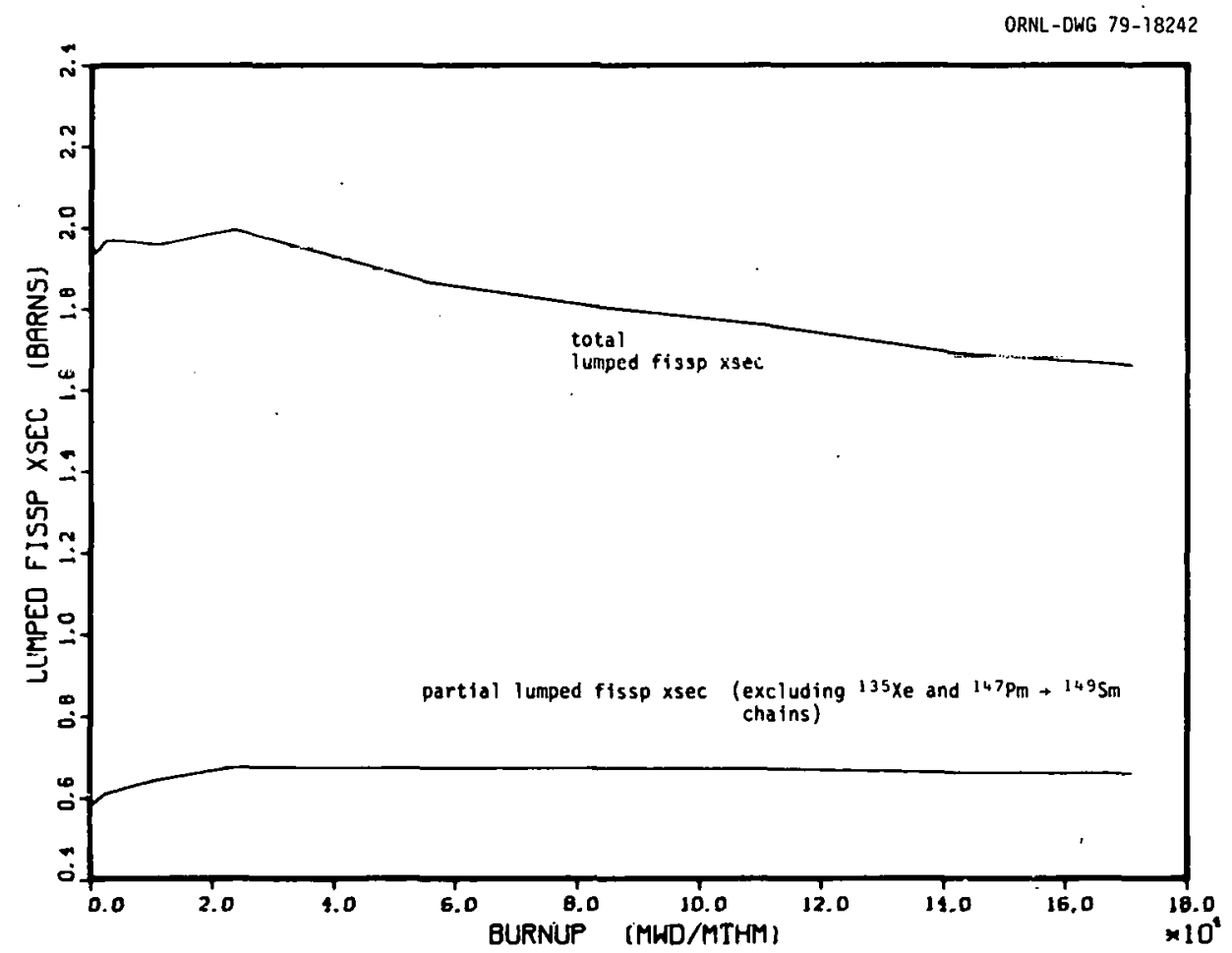

Fig. 3.11. Partial lumped fission product cross section versus burnup for moderated region spectra. 
C. Conclusions

The results just discussed were somewhat surprising, especially Fig. 3.5. The fact that the macroscopic cross section curves almost exactly parallel the fission product concentration line indicates that a one lumped fission product pair cross section is a very good model of the 181 individual nuclide cross sections. The slight deviation observed at low burnups is not too disconcerting sluce lie density, and therefore macroscopic cross section, is small in the low burnup reyiuns. Thus, uncertainties at low burnups have little effect on the overall neutronic performance of the reactor.

The final conclusion of this study is that the one lump fission product model is sufficiently accurate for reliable FMSR design studies. Although a multi-nuclide fission product set which explicitly accounted for the ${ }^{135} \mathrm{Xe},{ }^{147} \mathrm{Pm}$, and ${ }^{149} \mathrm{Sm}$ chains would be a more accurate representation, the added complexity and cost would outweigh the value of this additional accuracy. The multi-nuclide representation may be more applicable for detailed startup, shutdown, and other short-term transient analyses. It is felt that the uncertainty in the one-lump model is tollerable for initial design calculations and probably lies well within the uncertainty of the individual fission product cross sections.

\section{GENERATION OF LUMPED FISSION PRODUCT CROSS SECTIONS}

The conclusion from the above analysis was that a one-lump fission product model was sufficiently accurate for initial FMSR design calculations. However, it also pointed out that large variations in regional spectra are inherent in the FMSR design. Due to this fact, six 
50 group lumped fission product sets were generated, each representing a different geometrical region of a 1-dimensional FMSR model.

Figure 4.1 is a flow chart of the scheme used to obtain a six nuclide 50 group fission product library. Table 4.1 gives the burnup by region at which the collapse was performed. Increasing region number is in the direction of increasing radius. A burnup of approximately 83,000 MWD/MTHM was chosen for the fast region because this was near the midpoint of the expected burn. However, the moderated regions of the reference FMSR configuration never see high burnup fuel. Therefore, a nuclide distribution at about $10,000 \mathrm{MWD} / \mathrm{MTHM}$ was utilized for the two moderated region lumped fission products.

The collapse from the 126 group format to a 47 group library was done in the standard way utilicing the XSDRNPM ${ }^{7}$ module of the AMPX ${ }^{7}$ modular code system. The collapse to a 47 group level was first performed because of certain energy group boundary requirements for the 50 group library format specified by BNL. The 50 group boundaries were not a subset of the available 126 group fission product library. In most cases, the boundaries were close enough as not to cause any significant crrors. However, in three distinct cases the 50 group library had a finer group structure than the 126 fine-group library. For example, group 34 and 35 in the 50 group set were contained in group 111 of the 126 group library. To overcome this difficulty, the collapse in XSDRNPM was performed to a 47 group format, essentially ignoring the finer group structure in the 50 group library for the three cases of interest. The 47 group library was then extended to the 50 group format specified by BNL by dividing groups 34,35 , and 42 into two equal lethargy group widths. This was performed in a small FORTRAN code written specifically 


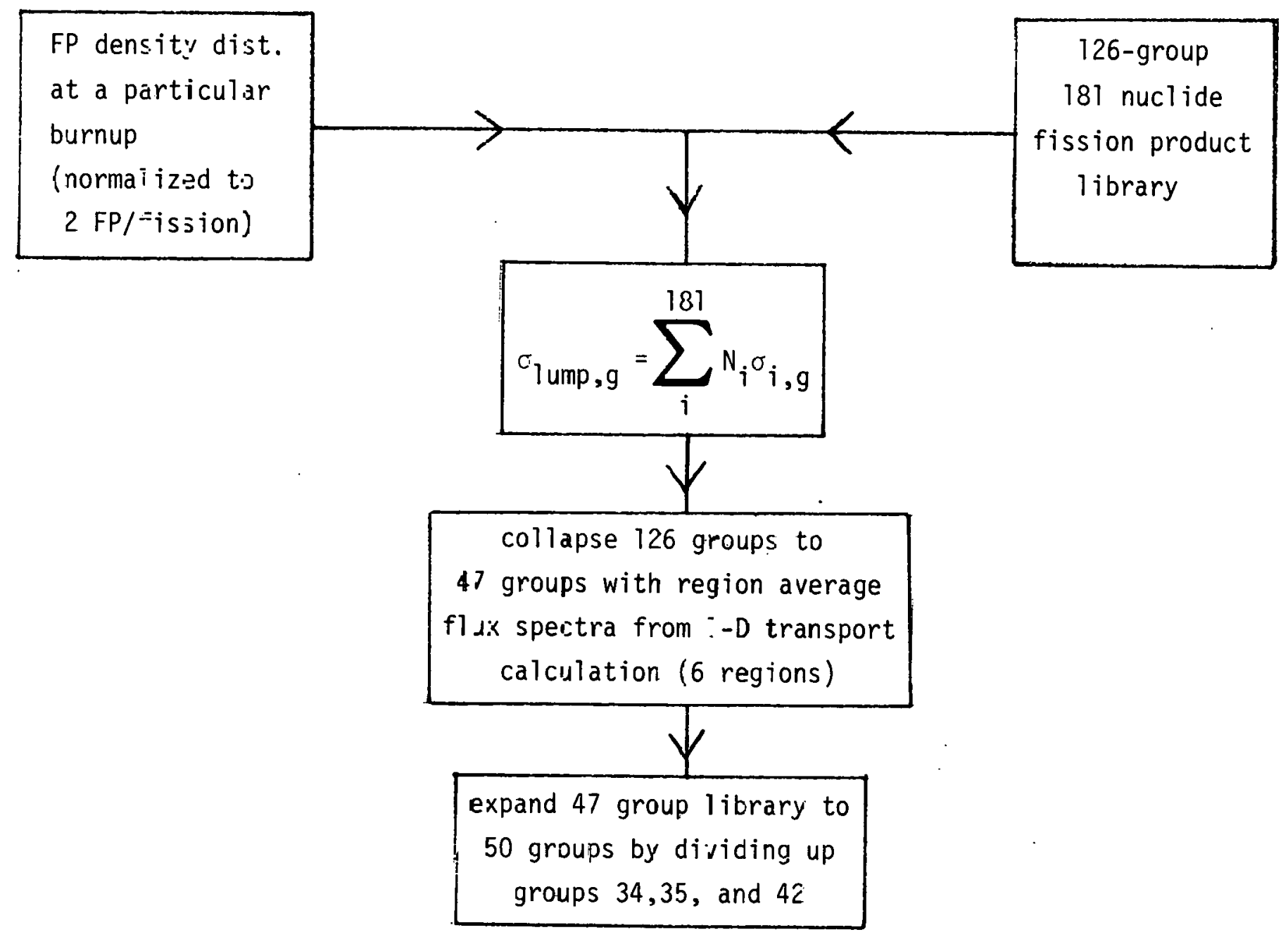

Fig. 4.1. Flow shart for generatior. of 50-group lumped fission procuct cross sections. 
Table 4.1 Burnup and Spectral Region

by FMSR Zone

\begin{tabular}{ccl}
\hline FMSR zone & $\begin{array}{c}\text { Burnup } \\
\text { (MWD/MTHM) }\end{array}$ & \multicolumn{1}{c}{ Spectral region } \\
\hline 1 & 82749 & central fast core \\
2 & 82749 & fast core \\
3 & 82749 & fast core \\
4 & 82749 & outer fast core \\
5 & 10163 & inner moderated region \\
6 & 10163 & outer moderated region
\end{tabular}

for this purpose, with special consideration given to handling the scattering matrix in a consistent manner.

The fission product cross sections generated utilizing the above scheme are plotted in Figs. 4.2 and 4.3, displaying the microscopic absorption and total cross sections respectively. The first zone in the fast and moderated regions were chosen as representative of the whole region. In fact, the 50-group representation is suffiriently detailed that the differences within a region (fast or moderated) are negligible. Thus, at the 50-group level only two lumped fission products are really needed rather than six lumps. Also, as observed from Figs. 4.2 and 4.3, differences between the fast and moderated regions are relatively small at low energies and completely negligible at high energies. The variation at the low end of the spectrum is mainly due to the different burnup/nuclide distribution employed in the collapse to one lumped fission producl. 
It should be emphasized that Figs. 4.2 and 4.3 confirm the results obtained from the 1-group analysis discussed previously. From these plots one can conclude that at high energies the fission product microscopic absorption and total cross section is constant with burnup. At low energies, however, the microscopic cross sections are weak functions of burnup with a maximum variation of about $10 \%$ over the burnup interval of 10,000 to $80,000 \mathrm{MWD} / \mathrm{MTHM}$. These observations support the conclusion that a one-lump fission product representation is sufficient for FMSR design analysis.

Finally, it should be noted that due to time limitations the final fission product cross sections generated in this study have not been utilized at ORNL. However, no problems with use of the fission product library is anticipated.

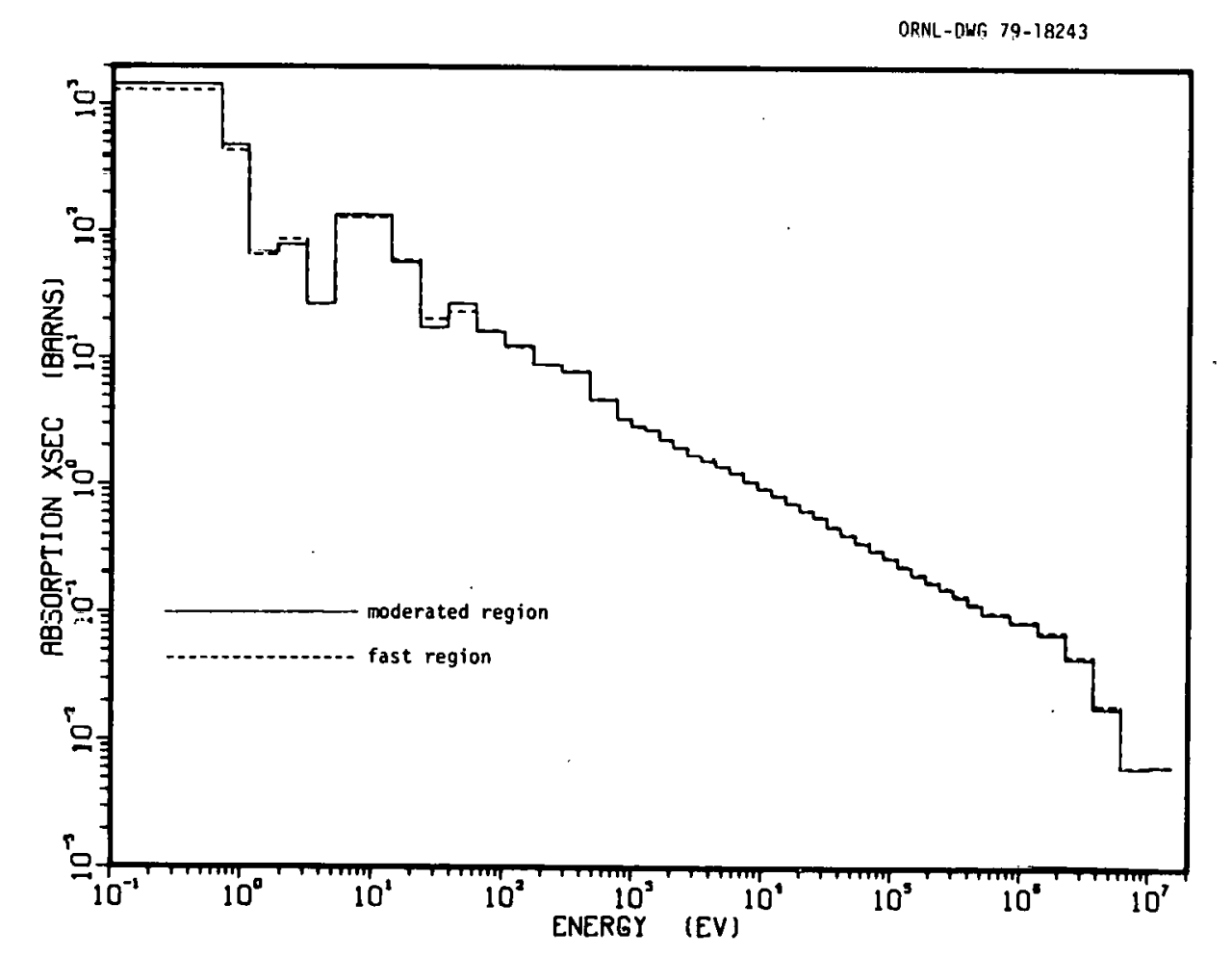

Fig. 4.2. 50-group fission product pair microscopic absorption cross section. 


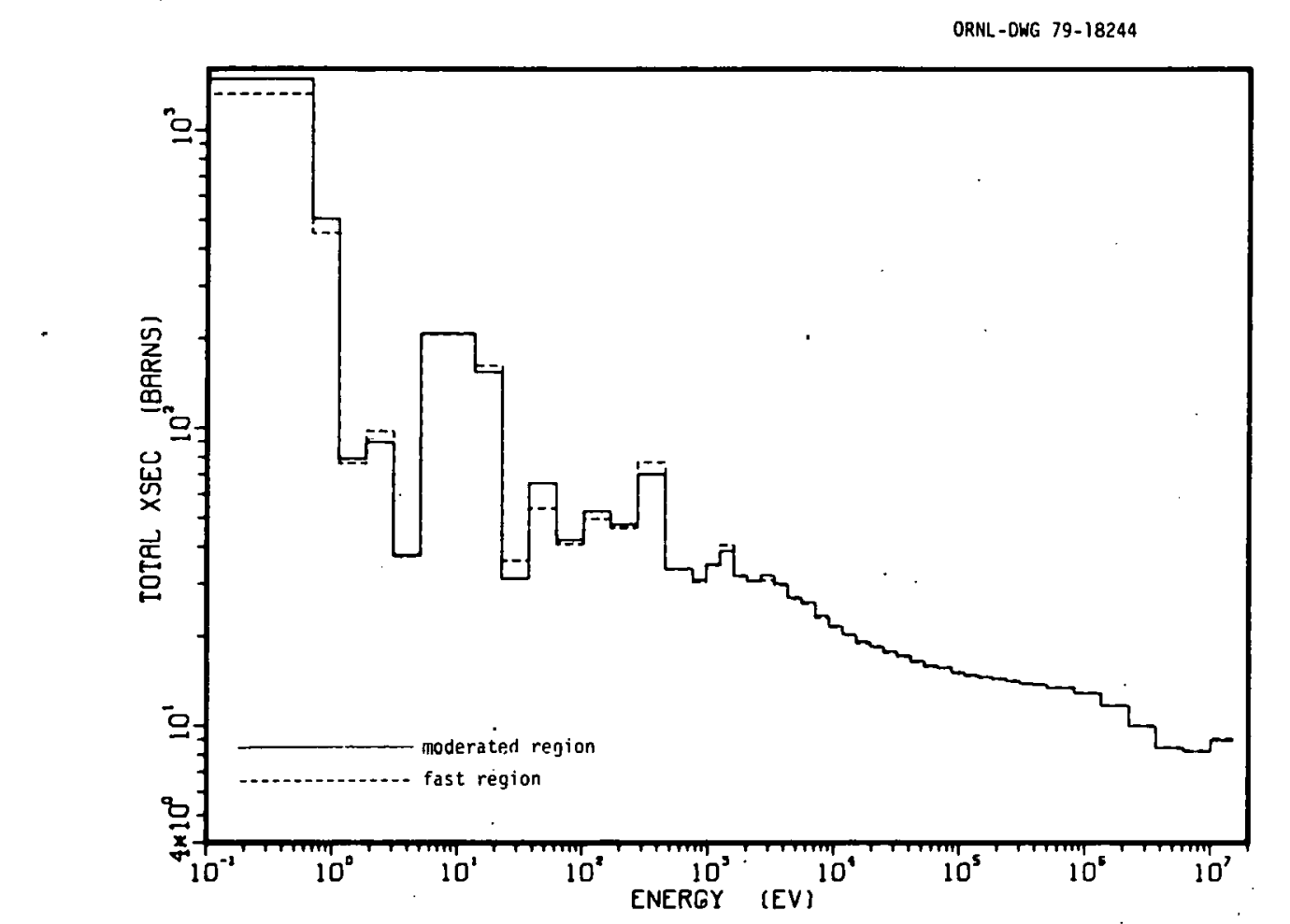

Fig. 4.3. 50-group fission product pair microscopic total cross section. 


\section{REFERENCES}

1. G. J. Fisher and R. J. Cerbone, "The Fast-Mixed Spectrum Reactor Interim Report Initial Feasibility Study," BNL 50976, Brookhaven National Laboratory (January 1979).

2. T. J. Burns and J. R. White, "Preliminary Neutronic Analysis of a Fast-Mixed Spectrum Reactor (FMSR)," ORNL/TM-6854, Oak Ridge National Laboratory (August 1979).

3. M. A. Bjerke, "126 Group ENDF/B-IV Fission Product Cross Sections," ORNL, private communication (December 1978).

1. K. B, K1Aman el a1., "LIB-IV, A Library of Gromp Constanta for Nuclear Reactor Calculations," LA-6260-MS, Los Alamos Ścientific Laboratory (1976).

5. M. J. Bell, "ORIGEN - The ORNL Isotope Generation and Depletion Code," ORNL-4628, Oak Ridge National Laboratory (May 1973).

6. T. B. Fowler, D. R. Vondy, and G. W. Cunningham, "Nuclear Reactor Core Analysis Code: CITATION," ORNL-TM-2496, Rev. 2, Oak Ridge National Laboratory (July 1971).

7. N. M. Greene, J. L. Lucius, L. M. Petrie, W. E. Ford, III, J. E. White, and R. Q. Wright, "AMPX: A Modular Code System for Generating Coupled Multigroup Neucron-Gauma Libraries from ENDF/B," ORNL/TM3706, Oak Ridge National Laboratory (March 1976). 


\author{
ORNL/TM- 7091 \\ Distribution Category \\ UC-77
}

INTERNAL DISTRIBUTION

1. L. S. Abbott

2. D. E. Bartine

3. J. E. Bigelow

4. W. D. Burch

5-7. T. J. Burns

8. J. E. Carpenter

9. G. F. Flanagan

10. U. Gat

11. F. J. Homan

12. J. L. Hu11

13. D. T. Ingersoll

14-24. P. R. Kasten

25. F. C. Maienschein

26. R. W. Peelle

27. D. L. Selby
28. C. 0. Slater

29. I. Spiewak

30. C. C. Webster

31-33. J. R. White

34. L. R. Williams

35. P. Greebler (consultant)

36. W. B. Loewenstein (consultant)

37. R. Wilson (consultant)

38-39. Central Research Library

40. ORNL Y-12 Technical Library Document Reference Section

41-42. Laboratory Records Dept.

43. Laborat ory Records - ORNL RC

44. ORNL Patent Office

45. EPD Reports Office

46. H. Goldstein (Consultant)

EXTERNAL DISTRIBUTION

47-48. Director, Division of Reactor Research and Technology, DOE, Washington, D.C. 20545

49. Assistant Manager, Office of Energy Research and Development, DOE-ORO

50-215. For distribution as shown in TID-4500 Distribution Category UC-77, Gas-Cooled Reactor Technol.ogy 